\title{
Correspondence
}

\section{Atlantoaxial subluxation and spinal cord compression in psoriatic arthropathy}

Sir, We read with interest the report by Pease and Pozo on atlantoaxial subluxation and spinal cord compression in psoriatic arthropathy. ${ }^{1}$ It appears, however, that even in the age of computerised literature searches one can fail when looking for specialised data. The authors state quite correctly that the incidence of atlantoaxial subluxation (AAS) in psoriatic arthropathy is uncertain. The risk of AAS in psoriatic arthropathy, however, and in other forms of seronegative spondylarthritis has been reported, as has severe neurological dysfunction resulting from cord compression due to psoriatic AAS. ${ }^{2}$

The case presented by Pease and Pozo shows, in the lateral cervical radiography, good bone structures in the occipitocervical junction and, as there is no sign of vertical $\mathrm{C} 2$ subluxation one must assume that the atlantoaxial facet joints are intact. ${ }^{34}$ Thus the AAS must be caused by ligamentous laxity. ${ }^{5}$ It is known that involvement of ligamentous tissues is more frequent in psoriatic arthropathy than in seropositive rheumatoid polyarthritis.

The initial treatment with skull traction was certainly correct, but extension reduces AAS more effectively than traction. $^{6}$

Further, the authors report a C5 motor defect on the left and present a neutral position lateral cervical radiography showing subaxial changes at $\mathrm{C} 4-5$ and $\mathrm{C5}-6$ levels. In inflammatory diseases, subaxial instabilities associated with soft tissue proliferation inside the spinal canal are often the cause of radiculopathy. ${ }^{36}$ In this case the neurological problems were initiated by minor trauma to the skull. At least theoretically the transient spinal cord trauma could have been either at the atlantoaxial level or, alternatively, subaxially.

This article is valuable confirmation of previous reports.
Hospital of Invalid Foundation,
S S SANTAVIRTA Tenholantie 10 ,

00280 Helsinki 28,

and The Fourth Department

of Internal Medicine,

University Central Hospital,

00170 Helsinki, Finland

\section{References}

1 Pease C T. Pozo J L. Atlantoaxial subluxation and spinal cord compression in psoriatic arthropathy. Ann Rheum Dis 1987; 46: $717-8$.

2 Santavirta S, Slätis P, Sandelin J, Lindqvist C. Konttinen Y T. Atlantoaxial subluxation in patients with seronegative spondylarthritis. Rheumatol Int 1987: 7: 43-6.

3 Santavirta S. Konttinen Y T. Sandelin J. Rheumatoid cervical spine: natural history and indications of surgical treatment. Sapporo Med J 1987; 56: 429-34.

4 Santavirta S. Hopfner-Hallikainen D. Paukku P. Sandelin J. Konttinen Y T. Atlantoaxial facet joint arthritis in the rheumatoid cervical spine. J Rheumatol (in press).

5 Konttinen Y T, Bergroth V, Santavirta S, Sandelin J. Inflammatory involvement of cervical spine ligaments in rheumatoid arthritis patients with atlantoaxial subluxation. $J$ Rheumatol 1987; 14: 531-4.

6 Santavirta S, Kankaanpää U, Sandelin J, Laasonen E. Konttinen Y T. Slätis P. Evaluation of patients with rheumatoid cervical spine. A review. Scand J Rheumatol 1987; 16: 9-16.

\section{Serum cytidine deaminase as a laboratory test for acute inflammation in rheumatoid arthritis}

SIR, The report by Thompson et al of raised levels of cytidine deaminase (CD) in the serum and synovial fluid of patients with rheumatoid arthritis (RA) raised the exciting prospect of a laboratory test more closely related to acute inflammation than any of those currently used in the study of inflammatory joint diseases. ${ }^{1}$ We wish to report our experience in the use of serum CD measurement in RA.

We studied 19 patients with definite/classical RA with varying degrees of disease activity. Clinical measurements included count of total number of involved joints, number of swollen joints, Ritchie articular index, grip strength, duration of morning stiffness, time to onset of fatigue, fatigue analogue scale, pain analogue scale, and patient/ physician global assessments of current status. Patients were ranked according to each measurement and a global ranking of disease severity was constructed on the basis of the sums of individual rankings. Routine laboratory tests included complete blood count, erythrocyte sedimentation rate (ESR), urine analysis, serum electrolytes, glucose, urea, creatinine, total protein, albumin, hepatic enzymes, rheumatoid factor, $C$ reactive protein (CRP), antinuclear antibody, and quantitative immunoglobulins. A global ranking of severity of laboratory abnormalities was also constructed. CD was measured by the technique of Jones et $a l^{2}$ at room temperature on serum samples previously frozen at $-20^{\circ} \mathrm{C}$.

We obtained a mean (SD) value for serum $C D$ of 4.3 $(2 \cdot 2) \mathrm{U} / \mathrm{ml}$ for our 19 patients. This is slightly lower than the figure of $5.5(2.3) \mathrm{U} / \mathrm{ml}$ reported by Thompson $e t$ al, but comparable. Our range of 1.3 to $10.7 \mathrm{U} / \mathrm{ml}$ appears almost identical to that illustrated in Fig. 2 of their paper. Eight patients had levels $>4 \mathrm{U} / \mathrm{ml}$ (i.e., more than $2 \mathrm{SD}$ above the normal mean of Thompson et al).

Regrettably, we were able to show very little relation between the patients' clinical status and their $C D$ levels. 